\title{
FAKTOR-FAKTOR YANG MEMPENGARUHI STAF PENGAJAR DI INSTITUSI PENDIDIKAN TINGGI UNTUK MENGGUNAKAN MULTIMEDIA
}

\author{
Rinaldi*, Efrizon \\ Jurusan Teknik Elektro, Politeknik Negeri Padang \\ Kampus Limau Manis, Padang, Sumatera Barat \\ *Kontak penulis: Tel: +6281372879090, E-mail: r.rinaldi@ymail.com
}

\begin{abstract}
This study is a descriptive study of the application towards multimedia that conducted in higher institution, West Sumatera with the objectives of assessing the factors affecting multimedia application in higher institution lecturers. It employed a survey questionnaire to collect respondents' responses by using Likert-5 point type scales. It was conducted on 250 lecturers by using stratified random sampling from three types of higher institutions. Data collected and analyzed by using Statistical for the Social Sciences 19.0 (SPSS 19.0). Descriptive analysis shows that factors affecting multimedia application are limited amount of equipments, less support from the institution, no confidence in using multimedia for teaching, damaged equipments, insufficient time to prepare multimedia-based teaching materials, not enough salaries to assist in carrying out their duties properly, increased teaching workloads, ineffective multimedia training and no rewards or incentives from the institution for using multimedia in teaching. As conclusion, this study can be used by the relevant authorities to take action in improving education.
\end{abstract}

\begin{abstract}
Abstrak
Penelitian ini merupakan penelitian deskriptif mengenai penggunaan multimedia yang dilakukan di institusi pendidikan tinggi di Sumatera Barat yang bertujuan untuk mengetahui faktor-faktor yang mempengaruhi penggunaan multimedia dalam kalangan staf pengajar. Penelitian ini menggunakan kuesioner untuk mengumpulkan jawaban responden dengan menggunakan skala Likert-5 poin. Penelitian dilakukan terhadap 250 staf pengajar yang berasal dari 3 jenis institusi pendidikan tinggi dengan menggunakan stratified random sampling. Data dikumpulkan dan analisis dengan menggunakan Statistical Package for the Social Sciences 19.0 (SPSS 19.0). Analisis deskriptif menunjukkan bahwa faktor yang mempengaruhi penggunaan multimedia adalah jumlah peralatan yang terbatas, dukungan yang kurang dari institusi, tidak percaya diri dalam menggunakan multimedia untuk mengajar, peralatan yang rusak, waktu yang tidak cukup untuk menyiapkan bahan ajar berbasis multimedia, gaji yang tidak cukup untuk membantu dalam melaksanakan tugas, banyaknya beban kerja, pelatihan multimedia yang tidak efektif dan tidak ada imbalan atau insentif dari institusi untuk menggunakan multimedia dalam pengajaran. Sebagai kesimpulan, penelitian ini dapat digunakan oleh otoritas terkait untuk mengambil tindakan dalam meningkatkan pendidikan.
\end{abstract}

Katakunci: Multimedia, masalah penggunaan multimedia, institusi pendidikan tinggi, staf pengajar, penelitian deskriptif 


\section{Pendahuluan}

Perkembangan teknologi telah mendorong perubahan di dunia pendidikan. Perubahan mencakup banyak aspek dalam bidang pengajaran, teknik pembelajaran dan kurikulum. Proses pengajaran dan pembelajaran dengan menggunakan metode konvensional yang cenderung banyak mengandalkan ceramah dan hanya berdasarkan buku-buku, tidak lagi menjamin efektivitas proses pengajaran dan pembelajaran (Herrington \& Herrington 1998). Selain itu, perkembangan teknologi juga dapat dimanfaatkan sebagai sarana untuk menguji dan menantang pemikiran, kapasitas, kemampuan dan imajinasi mahasiswa. Misalnya, subjek sejarah peradaban Islam yang diajarkan hanya dengan menggunakan metode ceramah dapat membuat mahasiswa merasa bosan dan sering menyebabkan mengantuk dan kehilangan minat belajar. Namun, hal ini dapat diantisipasi dengan membuat bahan pembelajaran menjadi menarik dan mudah dimengerti jika staf pengajar menyajikan melalui media bervariasi seperti multimedia.

Pada masa kini, penggunaan multimedia dalam proses pengajaran dan pembelajaran banyak menarik perhatian kalangan ahli pendidikan. Sebagian berpendapat bahwa multimedia memiliki dampak positif dan dapat meningkatkan efektivitas pembelajaran mahasiswa. Multimedia berbasis teknologi informasi dan komunikasi telah membawa semangat baru dalam dunia pendidikan. Multimedia dianggap dapat mengurangi beban kognitif mahasiswa dalam menerima proses pembelajaran (Mayer \& Moreno 2003).

Menyadari pentingnya multimedia dalam dunia pendidikan, maka banyak ahli pendidikan melakukan penelitian tentang penggunaan multimedia dalam kalangan staf pengajar karena mereka adalah individu yang paling dekat dengan siswa. Multimedia merupakan media yang mencakup hypertext, audio, video, animasi, simulasi dan interaktivitas yang membuat proses belajar kognitif menjadi praktis. Keberadaannya dapat merangsang pikiran mahasiswa dalam memahami bahan ajar dengan memvisualisasikan konsep pelajaran yang sulit untuk dipahami ketika hanya melalui metode ceramah. Dengan demikian, penelitian ini bermaksud untuk membahas 
permasalahan atau faktor-faktor yang mempengaruhi staf pengajar untuk menggunakan multimedia dalam proses pengajaran dan pembelajaran.

\section{Pernyataan Masalah}

Penggunaan multimedia dalam dunia pendidikan memiliki fenomena tersendiri. Hal ini karena penggunaan multimedia memiliki banyak keuntungan namun ia masih memiliki hambatan untuk mengakomodasi aplikasinya dalam proses pengajaran dan pembelajaran. Mohd. Izham (2007) melaporkan bahwa banyak para staf pengajar tidak memiliki kepercayaan diri untuk menggunakan multimedia di kelas. Penelitian lain iaitu Melvina dan Jamaluddin (2010) menyatakan bahwa kurangnya penggunaan multimedia dipengaruhi oleh sikap negatif dalam kalangan staf pengajar dan kurangnya pengetahuan terhadap penggunaan multimedia. Faktor tersebut hanya segelintir faktor yang mempengaruhi penggunaan multimedia dalam proses pengajaran dan pembelajaran. Dengan demikian, masih ada faktor lain yang mempengaruhi aplikasi multimedia dalam pengajaran. Oleh itu, masalah yang dihadapi dalam penelitan ini adalah, apakah faktor-faktor yang mempengaruhi staf pengajar untuk menggunakan multimedia dalam proses pengajaran dan pembelajaran?

\section{Tujuan Penelitian}

Penelitian ini bertujuan untuk mengetahui faktor-faktor apa saja yang mempengaruhi staf pengajar di institusi pendidikan tinggi untuk menggunakan multimedia dalam proses pengajaran dan pembelajaran?

\section{Metodologi}

Penelitian dilakukan terhadap 250 staf pengajar yang mengajar di universitas, institut dan sekolah tinggi yang berada di Sumatera Barat. Penelitian ini menggunakan metode stratified random sampling. Metode ini dipilih karena populasi penelitian tidak homogen dalam hal faktor sosio-demografis seperti jenis kelamin, pendidikan atau kualifikasi akademik, usia, jenis institusi, pengalaman mengajar, pelatihan dan jumlah beban kerja. Dengan demikian, metode stratified random sampling memilih 
sampel di setiap strata sehingga dapat mewakili populasi yang heterogen tersebut (Brymer \& Cramer 2005).

Penelitian juga dilaksanakan dengan menggunakan kuesioner sebagai instrumen untuk mengumpulkan data terhadap faktor-faktor yang mempengaruhi penggunaan multimedia dalam pengajaran. Jawaban dalam kuesioner menggunakan skala Likert dengan 5 poin. Kuesioner berisi 13 pernyataan yang mewakili faktor yang mempengaruhi penggunaan multimedia dalam pengajaran. Data yang dikumpulkan diolah dan dianalisis menggunakan SPSS versi 19.0. Analisis yang digunakan merupakan analisis deskriptif dengan menggunakan mean dan deviasi standard. Pernyataan yang memiliki mean yang termasuk kategori tingkat tinggi mengindikasikan bahwa hal tersebut merupakan faktor yang mempengaruhi penggunaan multimedia. Kategori mean dapat dilihat pada Tabel 1.

\begin{tabular}{ll}
\multicolumn{1}{c}{ Tabel 1 } & Kategori Mean \\
\hline Mean & Kategori \\
\hline $3.67-5.00$ & Tinggi \\
$2.34-3.66$ & Sederhana \\
$1.00-2.33$ & Rendah \\
\hline
\end{tabular}

Sumber: Mohd Aderi \& Rohani Ahmad (2009)

\section{Hasil Penelitian dan Pembahasan}

\section{Profil Sampel Penelitian}

Latar belakang sampel kajian atau responden dalam penelitian ini mencakupi jenis kelamin, kualifikasi akademik, usia, jenis institusi, pengalaman mengajar, pengalaman mengikuti pelatihan multimedia dan bebean kerja. Profil tersebut dapat dilihat pada Tabel 2.

Tabel 2 Profil Sampel Penelitian $(\mathrm{N}=250)$

\begin{tabular}{llll}
\hline & Latar Belakang & $\mathrm{N}$ & $\%$ \\
\hline Jenis kelamin & Perempuan & 124 & 49.6 \\
& Laki-laki & 126 & 50.4 \\
\hline
\end{tabular}




\begin{tabular}{llll}
\hline Kualifikasi & S2 & 132 & 52.8 \\
Akademik & S3 & 118 & 47.2 \\
\hline Usia & Kurang dari 30 tahun & 84 & 33.6 \\
& 30-40 tahun & 101 & 40.4 \\
& Lebih dari 40 tahun & 65 & 26.0 \\
\hline Jenis Institusi & Universitas & 80 & 32.0 \\
& Institut & 85 & 34.0 \\
& Sekolah Tinggi & 85 & 34.0 \\
\hline Pengalaman & Kurang dari 10 tahun & 83 & 33.2 \\
mengajar & 10 - 20 tahun & 101 & 40.4 \\
& Lebih dari 20 tahun & 66 & 26.4 \\
\hline Pelatihan & Ya & 222 & 88.8 \\
& Tidak & 28 & 11.2 \\
\hline Beban Kerja & 2 & 116 & 46.4 \\
& Lebih dari 2 & 134 & 53.6 \\
\hline
\end{tabular}

Sampel penelitian memiliki komposisi staf pengajar perempuan dan laki-laki yang hampir sama banyak yaitu 49,6\% staf pengajar perempuan dan 50,4\% staf pengajar laki-laki. Sebagian besar responden memiliki gelar magister $(52,8 \%)$ dibandingkan doktor $(47,2 \%)$. Kemudian, sebagian besar dari mereka berusia antara 30-40 tahun. Para staf pengajar yang dijadikan sampel penelitian berasal dari bermacam-macam institusi pendidikan tinggi di Sumatera Barat. Ini adalah bukti bahwa penelitian ini mencakup semua jenis institusi pendidikan tinggi. Sebagian besar staf pengajar juga telah memiliki pengalaman mengajar selama 10-20 tahun (40,4\%). Hampir semua staf pengajar juga telah menjalani pelatihan multimedia $(88,8 \%)$. Berdasarkan jumlah beban kerja, staf pengajar setidaknya memiliki 2 beban kerja tetapi kebanyakan dari mereka memiliki lebih dari 2 beban kerja. Sekitar 53,6\% memiliki lebih dari 2 beban kerja.

\section{Faktor-faktor yang mempengaruhi pengaruhi penggunaan multimedia}

Beberapa faktor yang disinyalir sebagai masalah dalam penggunaan multimedia dapat dilihat pada Tabel 3. 
Table 3 faktor yang disinyalir sebagai masalah dalam penggunaan multimedia

\begin{tabular}{|c|c|c|c|}
\hline Faktor & Mean & SD & \\
\hline Tidak percaya diri & 4.36 & 0.881 & Tinggi \\
\hline $\begin{array}{l}\text { Tidak mempunyai waktu untuk menyiapkan bahan ajar } \\
\text { dengan menggunakan multimedia }\end{array}$ & 4.23 & 0.847 & Tinggi \\
\hline Perasaan terbebani untuk menggunakan multimedia & 4.22 & 0.518 & Tinggi \\
\hline $\begin{array}{l}\text { Ketidaktahuan dalam menggunakan multimedia } \\
\text { menyebabkan malas menggunakan multimedia }\end{array}$ & 2.54 & 0.841 & Sederhana \\
\hline $\begin{array}{l}\text { Sukar memperoleh peralatan multimedia di tempat } \\
\text { mengajar karena jumlah yang terbatas }\end{array}$ & 4.45 & 0.614 & Tinggi \\
\hline $\begin{array}{l}\text { Gaji yang diterima tidak mencukupi untuk membantu } \\
\text { menjalankan tugas sebagai saf pengajar }\end{array}$ & 4.23 & 0.887 & Tinggi \\
\hline $\begin{array}{l}\text { Tidak mengetahui manfaat penggunaan multimedia } \\
\text { pengajaran }\end{array}$ & 2.07 & 0.924 & Rendah \\
\hline $\begin{array}{l}\text { Pelatihan yang diikuti tidak memberi manfaat terhadap } \\
\text { penggunaan multimedia pengajaran }\end{array}$ & 4.03 & 0.831 & Tinggi \\
\hline $\begin{array}{l}\text { Peralatan multimedia di tempat mengajar banyak yang } \\
\text { rusak }\end{array}$ & 4.36 & 0.960 & Tinggi \\
\hline $\begin{array}{l}\text { Tidak mendapatkan dukungan untuk menggunakan } \\
\text { multimedia dari pihak institusi }\end{array}$ & 4.38 & 0.549 & Tinggi \\
\hline $\begin{array}{l}\text { Tidak bersedia mengganti metode pengajaran tradisional } \\
\text { yang telah diterapkan dengan metode penggunaan } \\
\text { multimedia }\end{array}$ & 3.32 & 1.015 & Sederhana \\
\hline $\begin{array}{l}\text { Bersedia menggunakan multimedia apabila ada imbalan } \\
\text { atau insentif dari pihak institusi }\end{array}$ & 3.88 & 0.876 & Tinggi \\
\hline $\begin{array}{l}\text { Merasa bahawa multimedia tidak memberikan manfaat } \\
\text { terhadap pengajaran }\end{array}$ & 3.42 & 0.549 & Sederhana \\
\hline
\end{tabular}

- $\mathrm{SD}=$ deviasi standard

Tabel 3 menunjukkan mean dari masing-masing faktor yang disinyalir sebagai faktor yang mempengaruhi penggunaan multimedia. Sembilan faktor dari 13 faktor memiliki mean yang termasuk dalam kategori tinggi. Hal ini menunjukkan bahawa sembilan faktor tersebut merupakanfaktor yang mempengaruhi penggunaan multimedia dalam kalangan staf pengajar. Faktor-faktor tersebut adalah jumlah peralatan yang terbatas, 
dukungan yang kurang dari institusi, tidak percaya dalam menggunakan multimedia untuk mengajar, peralatan rusak, tidak cukup waktu untuk mempersiapkan bahan ajar berbasis multimedia, gaji yang tidak cukup untuk membantu dalam melaksanakan tugasnya dengan baik, menambah beban kerja, pelatihan multimedia yang tidak efektif dan tidak ada imbalan atau insentif dari institusi apabila menggunakan multimedia dalam mengajar.

Kurangnya infrastruktur dan peralatan atau kemudahan akses multimedia merupakan salah satu hambatan utama dalam penggunaan multimedia di kalangan staf pengajar. Hal ini juga diperkuat oleh penelitian yang dilakukan oleh Hajar Mohd Nor (2005), Sheingold dan Hadley (1990) serta Zuraidah Saidon (1998). Mereka menemukan bahwa fasilitas di institusi pendidikan tinggi masih belum lengkap dan mencukupi. Kurangnya perangkat multimedia kadang-kadang dapat menyebabkan staf pengajar malas menggunakan multimedia walaupun pengetahuan mereka dalam multimedia sudah baik dan memiliki sikap yang positif terhadap penggunaan multimedia dalam pengajaran.

Faktor utama lainnya adalah dukungan administrasi institusi sangat penting untuk mendorong staf pengajar untuk menerapkan perubahan yang diinginkan. Dukungan ini juga dapat berbentuk penyediaan sarana dan prasarana multimedia yang lengkap, imbalan atau insentif bagi staf pengajar yang telah menerapkan multimedia. Kurangnya waktu dan banyaknya jumlah beban kerja staf pengajar juga mempengaruhi mereka untuk menggunakan multimedia (Cuban 1993; Marcinkiewicz 1995) .

Kurangnya waktu dan banyaknya beban kerja dari staf pengajar menyebabkan mereka tidak dapat mempersiapkan bahan ajar berbasis multimedia. Selain itu, gaji yang diterima dirasa relatif rendah. Masalah bertambah dengan kurangnya dukungan dari institusi. Sementara itu, $88,8 \%$ staf pengajar telah mengikuti pelatihan multimedia, namun hasil penelitian menunjukkan bahwa tidak ada perbedaan yang signifikan penggunaan multimedia baik itu staf pengajar yang telah mengikuti pelatihan dan yang belum mengikuti pelatihan. Hal ini menunjukkan bahwa program pelatihan multimedia tersebut harus dievaluasi lebih lanjut. 
Temuan menarik lainnya dari penelitian ini adalah staf pengajar tidak memiliki kepercayaan diri dalam menggunakan multimedia untuk mengajar. Beberapa dosen tidak ingin terlihat lemah di mata mahasiswa karena kurnag mahir dalam menggunakan multimedia. Ini berdampak terhadap menurunnya kepercayaan diri mereka untuk menggunakan multimedia. Selain itu, persepsi bahwa mahasiswa memiliki pengetahuan multimedia yang lebih baik tertanam dalam benak para staf pengajar membuat mereka semakin tidak percaya diri.

\section{Kesimpulan}

Implikasi dari penelitian ini didedikasikan untuk institusi pendidikan tinggi dan kementerian pendidikan untuk mendukung penggunaan multimedia. Implikasi ini diharapkan dapat memberikan kontribusi untuk peningkatan penggunaan multimedia dalam kalangan staf pengajar. Dukungan nyata dari pihak yang berkaitan sangat penting.

\section{Daftar Pustaka}

Brymen, J. \& Cramer, D. 2005. Quantitative Data Analysis with SPSS 12 and 13: A Guide for Social Scientist. Hove: Routledge.

Cuban, L. 1993. How Teachers Taught: Constancy and Change in American Classrooms. New York: Teachers College Press.

Hajar Mohd. Nor. 2005. Condition facilitating the implementation of information communication technology integration in the Malaysia smart school. Thesis. Universiti Putra Malaysia.

Herrington, J. \& Herrington, A. 1998. Authentic assessment and multimedia: how university students respond to a model of authentic assessment. Higher Education Research and Development 17(3): 305-322.

Marcinkiewicz. 1994. Computers and teachers: factors influencing computer use in the classroom. Journal of Research on Computing in Education 26(2): 220237. 
Mayer, R. \& Moreno, R. 2003. Nine ways to reduce cognitive load in multimedia learning. Educational Psychologist 38(1): 43-52.

Melvina, Chung Hui Ching \& Jamaludin Badusah. 2010. Sikap guru bahasa terhadap pengunaan teknologi maklumat komunikasi (ICT) dalam pengajaran di sekolah-sekolah rendah di Bintulu, Sarawak. Jurnal Pendidikan Malaysia 35(1): 59-65.

Mohamad Izham Mohamad Hamzah \& Noraini Attan. 2007. Tahap kesediaan guru sains dalam penggunaan teknologi maklumat berasaskan komputer dalam proses pengajaran dan pembelajaran. Jurnal Teknologi 46(E): 45-60.

Mohammed Sani Hj. Ibrahim, Jamalul Lail Abdul Wahab, Mohd. Izham Mohd. Hamzah \& Warnoh Katimah. 1999. Kajian keberkesanan perlaksanaan program latihan guru sekolah bestari. Projek Penyelidikan G9/99. Fakulti Pendidikan Universiti Kebangsaan Malaysia.

Mohd Aderi Che Noh \& Rohani Ahmad Tarmizi. 2009. Persepsi pelajar terhadap amalan pengajaran tilawah al-quran. Jurnal Pendidikan Malaysia 34: 93 - 109.

Sheingold, K \& L, M. 1990. Accomplished TeachersIintegrating Computers into Classroom Practice. New York: Bank Street College.

Zuraidah Saidon. 1998. Factor affecting the implementation of information technology in secondary schools within the Klang Valley. Tesis Sarjana. Universiti Malaya. 